\title{
Comparison of particle processing by two introduced suspension feeders: selection in Crepidula fornicata and Crassostrea gigas
}

\author{
Peter G. Beninger*, Priscilla Decottignies, Freddy Guiheneuf, Laurent Barillé, \\ Yves Rincé
}

Laboratoire de Biologie Marine, Faculté des Sciences, Université de Nantes, 44322 Nantes Cedex 3, France

\begin{abstract}
In order to understand the trophic interactions between 2 introduced suspension feeders in Europe, the North American slipper limpet Crepidula fornicata (Gastropoda) and the Pacific oyster Crassostrea gigas (Bivalvia), it is first necessary to determine the characteristics of their feeding mode. In particular, no information has been previously available concerning the capacity for qualitative particle selection-typical of $C$. gigas-in C. fornicata. Firstly, we investigated the anatomical-functional potential for selection in the feeding structures of $C$. fornicata using scanning electron microscopy, video-endoscopy, histology and mucocyte characterization. Secondly, the relative performance of qualitative selection by these 2 species was compared under experimental particle concentrations similar to those in the natural habitat, using the naturally occurring diatom Coscinodiscus perforatus var. pavillardii and the live cell/empty, cleaned frustule approach. In contrast to $C$. gigas, the feeding structures of $C$. fornicata showed no anatomical or functional potential for qualitative selection. Furthermore, although $C$. gigas demonstrated significant qualitative selection in selection experiments, C. fornicata demonstrated none. This fundamental difference in suspension-feeding mode will predetermine the approaches that can be used in future studies on trophic interactions, and suggests that the degree of diet overlap will depend on the extent and time periods within which oysters engage in qualitative selection.
\end{abstract}

KEY WORDS: Crepidula $\cdot$ Crassostrea $\cdot$ Feeding $\cdot$ Selection

\section{INTRODUCTION}

The dynamics and underlying biodiversity of coastal ecosystems have been significantly altered by voluntary or involuntary introductions of allopatric suspension feeders that acquire the characteristics of invasive species (Davis \& Thompson 2000, Jackson et al. 2001, Wonham et al. 2005). In Europe, the involuntary introduction and establishment of the North American slipper limpet Crepidula fornicata (Gastropoda: Calyptraeidae) took place in several waves, beginning with the importation of the American Eastern oyster Crassostrea virginica in 1887, continuing with the massive American and Canadian warship arrival in continental Europe in 1944, and the importation of the Pacific oyster Crassostrea gigas to compensate for epidemic losses of the introduced Crassostrea angulata in the 1970s (Minchin et al. 1995, Blanchard 1997). Concern for the potential negative effects of these introductions has existed since the early 20th century (Orton 1912), but until recently, surprisingly little research had been conducted to characterize the mechanisms and amplitude of ecosystem alteration (de Montaudouin et al. 1999). Although currently distributed from Spain to Denmark, the highest densities (several thousand ind. $\mathrm{m}^{-2}$ ) are reported along the Atlantic coast of France (de Montaudouin \& Sauriau 1999, Thieltges et al. 2004). High densities of $C$. fornicata have been shown to have both negative and positive effects on ecosystem characteristics (de Montaudouin \& Sauriau 
1999, Vallet et al. 2001, Le Pape et al. 2004, Thieltges 2005).

The most highly productive French Atlantic coastal systems are used to support aquacultural production of the 'desired' introduced oyster species Crassostrea gigas, and it is for these regions that concern for potential negative effects of high densities of the suspensivorous slipper limpet is especially acute (Marteil 1965, Blanchard 1995, 1997, de Montaudouin et al. 1999). A small-scale study using artificial enclosures did not detect a significant alteration to the growth or condition index of oysters (de Montaudouin et al. 1999). It is thus important to understand the extent, if any, to which the diets of sympatric Crepidula fornicata and C. gigas overlap, in order to evaluate the eventual effect of trophic competition between these species in these human-altered ecosystems. Differences in the isotopic deviations of C. fornicata and C. gigas in the Oosterschelde, The Netherlands, suggested that these 2 suspension-feeders may not be competitors in the absence of food limitation (Riera et al. 2002).

Before direct comparison of diets e.g. through stomach contents and/or stable isotope analysis, it is necessary to delineate the basic feeding characteristics that can be expected to strongly influence trophic competition, notably clearance rates, retention, and selection. The clearance rates of Crassostrea gigas are substantially higher than those of Crepidula fornicata. In contrast, although both species retain particles within the same size range, retention of particles $<5 \mu \mathrm{m}$ by C. fornicata is markedly superior to that of C. gigas (Barillé et al. 2006). Indeed, C. fornicata was reported to retain particles of $1.2 \mu \mathrm{m}$ with an efficiency of $90 \%$ (Jørgensen et al. 1984). However, before concluding that trophic competition is possible, it is necessary to determine whether both species are capable of qualitative selection. Regardless of size-retention characteristics, the degree of trophic competition is altered if each species preferentially ingests different particle types. C. gigas is known to mediate qualitative selection ( Barillé et al. 1997, Bougrier et al. 1997) by both the gills and labial palps (Ward et al. 1998, Cognie et al. 2003). Comparable information is not yet available for $C$. fornicata. It is assumed that suspension-feeding gastropods are incapable of effecting selection because they lack the labial palps of bivalves (Declerck 1995), but to our knowledge this has never been experimentally demonstrated, and in any event certain bivalve gill types are themselves capable of selection (Ward et al. 1998, Beninger et al. 2004). In the present study, we investigated this by first examining the particle-processing structures of this species, both to further our basic understanding of the feeding process (as was recently attempted for the South American species Crepidula fecunda; Chaparro et al. 2002), and to determine whether they are anatomically and functionally capable of qualitative selection. Secondly, we compared the actual qualitative selection performance of both species via the live cell/empty, cleaned frustule approach, which was successfully applied to detect and quantify qualitative selection in previous studies (Cognie et al. 2003, Beninger et al. 2004).

\section{MATERIALS AND METHODS}

Feeding structures of Crepidula fornicata. General gill and radula organization: For scanning electron microscopy (SEM), 4 C. fornicata (longest shell axis $\sim 3 \mathrm{~cm}$ ) were sampled intertidally in Bourgneuf Bay $\left(47^{\circ} 4^{\prime} \mathrm{N}\right.$, $2^{\circ} 4^{\prime} \mathrm{W}$; France) in January 1998. The gills were dissected out, field-fixed in cold, slightly hypermolar $3 \%$ glutaraldehyde-cacodylate buffer $(\mathrm{pH} 7.2)$ for $7 \mathrm{~d}$, rinsed in cacodylate buffer for at least $4 \mathrm{~d}$, prepared for SEM by dehydration in an ascending ethanol series, $\mathrm{CO}_{2}$ critical-point dried, and sputter-coated with goldpalladium.

The radulae of 6 adult Crepidula fornicata were removed in the field in January 2001 and fixed in situ in a solution of $2.5 \%$ glutaraldehyde in a hyperosmotic $0.1 \mathrm{M}$ sodium cacodylate buffer. In order to observe both structural detail and natural condition, 3 of the radulae were transferred to $50 \%$ ethanol and cleaned of adhering mucus and particles using a fine artist's paintbrush, while the others were left in their original state. The radulae were then prepared for SEM as above. In order to observe the radula in its normal anatomical context, an additional specimen was fixed in toto, the radula partly extended, and processed as above. The gills and radulae were observed using a JSM $6400 \mathrm{~F}$ microscope operating at $15 \mathrm{kV}$.

Gill histology and mucocyte types: The gills of 3 adult Crepidula fornicata ( 3.5 to $4.5 \mathrm{~cm}$, collected from Bourgneuf Bay in January and February 2001) were dissected out and processed for topological histology and mucocyte typing as detailed by Beninger et al. (2003). The fixed gills were separated into 3 equal portions along the antero-posterior axis: anterior, median and posterior. Each portion was then divided into 2 samples, one destined for histological sections (allowing the precise determination of mucocyte location), and the other for whole-mount typing.

Gill portions were processed for histology, embedded in paraffin, and sectioned at $7 \mu \mathrm{m}$ for topological staining and $10 \mu \mathrm{m}$ for mucocyte staining. Thick sections were necessary in order to obtain sufficient colour density of mucocytes for positive identification: periodic acid-Schiff (PAS)-stained mucocytes in thinner sections do not contrast sufficiently. The modified Masson's trichrome protocol was used for topological staining, 
whereas the PAS-alcian blue (PAS-AB) procedure was used for mucocyte staining (Beninger et al. 2003). Extensive preliminary trials, extending to 30 min contact time for the PAS reagents, failed to reveal the presence of neutral or mixed mucopolysaccharide-containing mucocytes; optimum alcian blue contact time was $5 \mathrm{~min}$ for sections, and $4 \mathrm{~min}$ for whole mounts.

The procedure for whole mount mucocyte typing followed that described by Beninger et al. $(1993,2003)$. As was observed for histological sections, PAS-AB staining failed to reveal the presence of neutral or mixed mucopolysaccharide-containing mucocytes. Whole mount preparations were therefore stained exclusively with alcian blue. The stained, separated filaments were mounted in an aqueous mounting medium (Aquaperm) and sealed with nail polish.

Particle transport and ingestion: In order to relate the anatomical characteristics of feeding structures to their function, 10 Crepidula fornicata were prepared for video-endoscopy by milling a notch in the anterior extremity of the shell at least $1 \mathrm{~d}$ prior to endoscopy. All such specimens exhibited apparently normal feeding behaviour the following day (shell margin raised above substrate, pallial water flow established). A $4 \mathrm{~mm}$ diameter optical insertion tube (OIT) was used in conjunction with a fibre-optic light source and digital video camera, and images were recorded directly on computer hard disk. Individuals were acclimated to observation conditions at least $1 \mathrm{~h}$ prior to the start of observations. A mixture of Coscinodiscus perforatus var. pavillardii culture and mica/titanium dioxide reflective particles (to improve visualization of particle behaviour, mucus cords, and suspensions) was added to the observation chamber (Beninger et al. 2004) at the commencement of recording.

Selection experiments. Specimen sampling and maintenance: Large Crassostrea gigas (mean \pm SD: longest shell axis $=8.8 \pm 1.7 \mathrm{~cm}$, dry wt $=1.4 \pm 0.5 \mathrm{~g}$ ) and large Crepidula fornicata (mean \pm SD: longest shell axis $=4.8 \pm 0.3 \mathrm{~cm}$, dry weight $=0.6 \pm 0.2 \mathrm{~g}$ ) were sampled in Bourgneuf Bay in March 2005, transported to the laboratory, and cleaned of attached organisms and debris. They were maintained under conditions close to those of the sampling site $\left(T=16^{\circ} \mathrm{C}, \mathrm{S}=33\right)$ in an aerated, temperature-controlled, recirculating seawater system, using $0.22 \mu \mathrm{m}$ Milliporefiltered seawater and ultra-violet sterilization. Specimens were fasted for at least $1 \mathrm{wk}$ prior to experimentation, in order to purge gut contents and ensure feeding responses under experimental conditions.

Test microalgae: Coscinodiscus sp. was isolated from a plankton tow in December 2004 off Noirmoutier Island $\left(47^{\circ} 04^{\prime} \mathrm{N}, 2^{\circ} 20^{\prime} \mathrm{W}\right)$, and cultured as per Beninger et al. (2004) in ascending volumes of medium at 15 to $16^{\circ} \mathrm{C}$ under a $14 \mathrm{~h}$ photoperiod. The species was identified as Coscinodiscus perforatus var. pavillardii (Forti) Hustedt (Okuno 1970) via SEM of cleaned frustules ( $30 \%$ hydrogen peroxide incubation at 85 to $95^{\circ} \mathrm{C}$, reaction stopped with several drops of $1 \mathrm{M} \mathrm{HCl}$, frustules rinsed several times with distilled water). Although Crassostrea gigas is known to ingest Coscinodiscus perforatus (Cognie et al. 2003), ingestion of C. perforatus by Crepidula fornicata is unknown. At the conclusion of the experiments, 5 haphazardly selected $C$. fornicata were fed ad lib. with the C. perforatus var. pavillardii culture, and the feces and stomach contents recovered for determination of the presence of these diatoms.

A biometric study of cultured Coscinodiscus perforatus var. pavillardii was performed on 145 specimens examined under light microscopy using LUCIA G 4.80 (Nikon France) software, revealing a relatively uniform size distribution (mean \pm SD: diameter $=169 \pm$ $5 \mu \mathrm{m}$, pervalvar axis $=61 \pm 7 \mu \mathrm{m})$. The organic content of the cultures was determined by loss on ignition $\left(250 \mathrm{ml}\right.$ triplicates, $48 \mathrm{~h}$ drying time at $60^{\circ} \mathrm{C}, 4 \mathrm{~h}$ ignition time at $450^{\circ} \mathrm{C}$ ).

Empty, cleaned frustules of Coscinodiscus perforatus var. pavillardii were obtained using the hydrogen peroxide treatment described above, but with incubation at 65 to $75^{\circ} \mathrm{C}$ and constant microscopic inspection to ensure complete degradation of organic matter with minimal valve separation (Cognie et al. 2003, Beninger et al. 2004, Beninger \& Decottignies 2005). The stock of cleaned frustules was rinsed several times with filtered seawater and stored in $70 \%$ ethanol to prevent the growth of bacteria and the establishment of a biofilm.

Test mixtures of Coscinodiscus perforatus var. pavillardii thus contained various proportions of live cells, natural dead uncleaned cells, and empty, cleaned frustules. As it was only possible to characterize these mixtures post hoc through Sedgewick-Rafter counts, an effort was made to test 2 different mixtures, which corresponded to different total cell concentrations and percentage intact cells (Table 1), determined after completion of the experiments. It should be noted that the large size of $C$. perforatus var. pavillardii trans-

Table 1. Particulate composition (mean \pm SD) of inflow water of the 2 experimental conditions. TPM, total particulate matter; POM, particulate organic matter

\begin{tabular}{|lcccc|}
\hline & $\begin{array}{c}\text { Cell concentration } \\
\left(\text { cell } \mathrm{l}^{-1}\right)\end{array}$ & $\begin{array}{c}\text { Intact cell } \\
(\%)\end{array}$ & $\begin{array}{c}\text { TPM } \\
\left(\mathrm{mg} \mathrm{l}^{-1}\right)\end{array}$ & $\begin{array}{c}\text { POM } \\
\left(\mathrm{mg} \mathrm{l}^{-1}\right)\end{array}$ \\
\hline Condition 1 & $150 \pm 20$ & $47 \pm 2$ & $117.3 \pm 2.1$ & $26.7 \pm 2.4$ \\
Condition 2 & $317 \pm 30$ & $30 \pm 1$ & $130.6 \pm 0.6$ & $33.5 \pm 2.3$ \\
\hline
\end{tabular}


lated to low numerical particle concentrations (90 to 340 cells ml ${ }^{-1}$ ), but represented the naturally occurring total particulate matter (TPM) concentrations of Bourgneuf Bay in terms of mass (117 to $130 \mathrm{mg} \mathrm{ml}^{-1}$ ) (Haure \& Baud 1995).

Experimental protocol: Twelve Crassostrea gigas and 12 Crepidula fornicata were placed in individual flow-through clearance-study chambers as described by Palmer \& Williams (1980), with partial separations designed to produce a laminar flow of 3 to $4 \mathrm{l} \mathrm{h}^{-1}$ under experimental conditions. The medium used was $0.22 \mu \mathrm{m}$ Millipore-filtered natural seawater from north-east Noirmoutier Island; temperature and salinity were close to those of the maintenance conditions and the original collection site (mean $\pm \mathrm{SD}: T=17 \pm$ $1^{\circ} \mathrm{C}, \mathrm{S}=33 \pm 0.1$ ). Due to the fixation mode of $C$. fornicata, each individual was left attached to the empty shell immediately beneath (the bottom-most, and therefore largest, live specimen of each chain was used). The $C$. gigas and $C$. fornicata specimens were affixed to the chamber floors using a quick-set cementing paste; 1 empty oyster shell (left and right valves) and 1 empty limpet shell were used as sedimentation controls in separate chambers (hereafter designated as 'control').

The cultured Coscinodiscus perforatus var. pavillardii, spiked with empty, cleaned frustules as per Table 1, was added to the reservoir providing the inflow to test chambers. We investigated 2 experimental conditions (Table 1) to test the activation of selection mechanisms under conditions of (1) low total cell concentrations/high ( $50 \%$ ) proportions of intact cells, and (2) high total cell concentrations/low ( $\sim 30 \%)$ proportions of intact cells. Target concentrations were constrained by the concentrations achieved in laboratory large-volume cultures, and determined in water samples of the reservoir at intervals of 30 min until termination of the experiment at $120 \mathrm{~min}$.

Outflow of the control chambers was withdrawn at intervals of 30 min until termination of the experiment at $120 \mathrm{~min}$. Particle types and concentrations were determined for each sample, and averaged $( \pm \mathrm{SD})$ to yield a single value for the duration of the experiment. Pseudofeces production was allowed to occur up until $120 \mathrm{~min}$, at which time final water samples were collected and the easily recognized pseudofeces recovered using a micropipette. Water and pseudofeces samples were fixed in Lugol's solution for later particle typing and Sedgewick-Rafter counting (allowing the differentiation of live and empty cells). For each of the 2 experimental conditions, proportions of live and empty cells were determined in the chamber inflow water and in pseudofeces (not present in control chambers). A $1000 \mathrm{ml}$ volume of reservoir water was also filtered onto Whatman GF/F filters (porosity of $0.45 \mu \mathrm{m}$ ) for loss-on-ignition measurements of TPM, particulate inorganic matter (PIM), and particulate organic matter (POM) $(250 \mathrm{ml}$ quadruplicates, $48 \mathrm{~h}$ drying time at $60^{\circ} \mathrm{C}, 4 \mathrm{~h}$ ignition time at $450^{\circ} \mathrm{C}$ ).

Data analysis. The proportions of each cell type were arcsine-transformed (Sokal \& Rohlf 1995), and the resulting normally distributed, homoscedastic data were analysed using 1-way ANOVA, in order to compare live cell proportions in the pseudofeces and control chamber waters of both species. For each specimen, a selection index (SI; Ward et al. 1998, Cognie et al. 2003, Beninger et al. 2004 ) was calculated as follows

$$
\mathrm{SI}=\left[\left(P \times W^{-1}\right)-1\right] \times 100
$$

where $P$ is the percent of live cells present in the pseudofeces, and $W$ is the percent of live cells present in the outflow of the control Crassostrea gigas or Crepidula fornicata chambers. A 2-way ANOVA was used to compare the selection indices between conditions and species.

Our null hypothesis $\left(H_{0}\right)$ was that no qualitative selection occurs. In this event, no significant difference in percentages of live and empty cells would be observed between the control outflow water and pseudofeces, and no significant difference in selection indices would exist. Our experimental hypothesis $\left(H_{1}\right)$ was that qualitative selection occurs. In this event, the proportion of empty cells would be higher in the pseudofeces than in the corresponding control chamber outflow water, and significant differences in selection indices would be observed.

\section{RESULTS}

\section{General gill organization of Crepidula fornicata}

The general organization of the homorhabdic, nonreflected Crepidula fornicata gill conforms to the previous description by Orton (1912). It should be noted that despite the linear arrangement of the filaments at their insertion in the mantle, the complete absence of interfilamentar and mantle-filament cohesive structures results in a tuft-like spatial organization in specimens removed from their shells, such that distal transverse histological sections do not convey the linear arrangement of the gill base or of the filaments in an undisturbed animal (Fig. 1a,c,d). The filament supporting rods are quite massive in C. fornicata, enabling the distally unattached filaments to maintain their linear shape (Fig. 1e).

The lateral cila are quite long compared with the frontal and abfrontal cilia ( 25 to $30 \mu \mathrm{m}$ vs. 6 to $7 \mu \mathrm{m}$, Fig. $1 \mathrm{~b}, \mathrm{e})$. The extremely regular width of the ciliated tracts can only be due to a constant cell number in each tract (Fig. 1b,e). 
Only acid mucopolysaccharide (AMPS)-containing mucocytes were found on the Crepidula fornicata gill filaments, both in whole mounts and in histological sections, and all traces of MPS stained exclusively with alcian blue (Fig. 1f). Most mucocytes were found on the abfrontal surface, with fewer on the frontal surface
(Fig. 1e), indicating that most of the frontal surface mucus probably derives from the endostyle. Although counts were not performed, the dorsal region (including the endostyle situated just dorsal to the gill insertion) presented a consistently denser array of AMPS mucocytes.
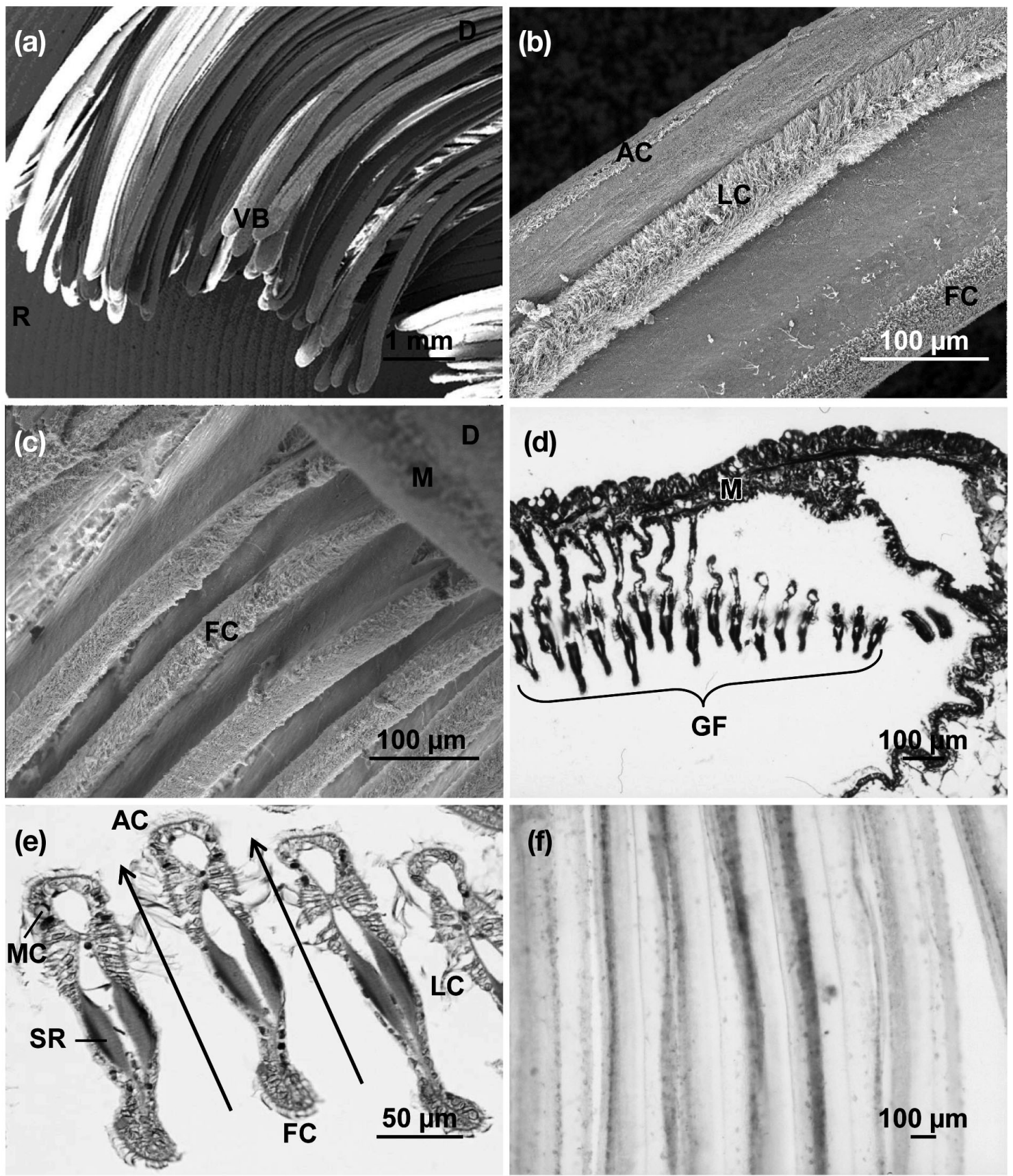

Fig. 1. Crepidula fornicata. (a-c) Scanning electron micrographs of gill filaments. (a) Tuft-like organization of the gill in shucked specimen. D, dorsal; R, right; VB, ventral bulb. (b) Lateral view of a gill filament. AC, abfrontal cilia; FC, frontal cilia; LC, lateral cilia. (c) View of frontal surface of gill base. M, mantle. (d,e) Light micrographs of transverse histological sections of gill filaments (GF) stained with Masson's trichrome. Arrows, water flow; MC, mucocyte; SR, supporting rod. (f) Black and white photomicrograph of gill whole-mount stained with PAS-AB. Note numerous mucocytes (small dots) 


\section{Radula structure}

As is the case for almost all mesogastropods (Voltzow 1994), the Crepidula fornicata radula is taenioglossate (formula 2-1-R-1-2). A notable feature is the long, slender, inwardly antero-posteriorly arching double row of marginal teeth, which become splayed when the anterior region is bent, as in the plesiomorphic flexoglossate feeding mode (Guralnick \& Smith 1999; Fig. 2a-e). The roughly triangular rachidian and lateral teeth are di- rected posteriorly, presenting several serrations on their edges (Fig. 2f). No significant signs of wear were observed on the teeth of any of the 6 specimens studied.

\section{Feeding functional observations}

Our video-endoscopic observations of feeding Crepidula fornicata corroborated the main points outlined by Chaparro et al. (2002) for C. fecunda: dorso-ventral
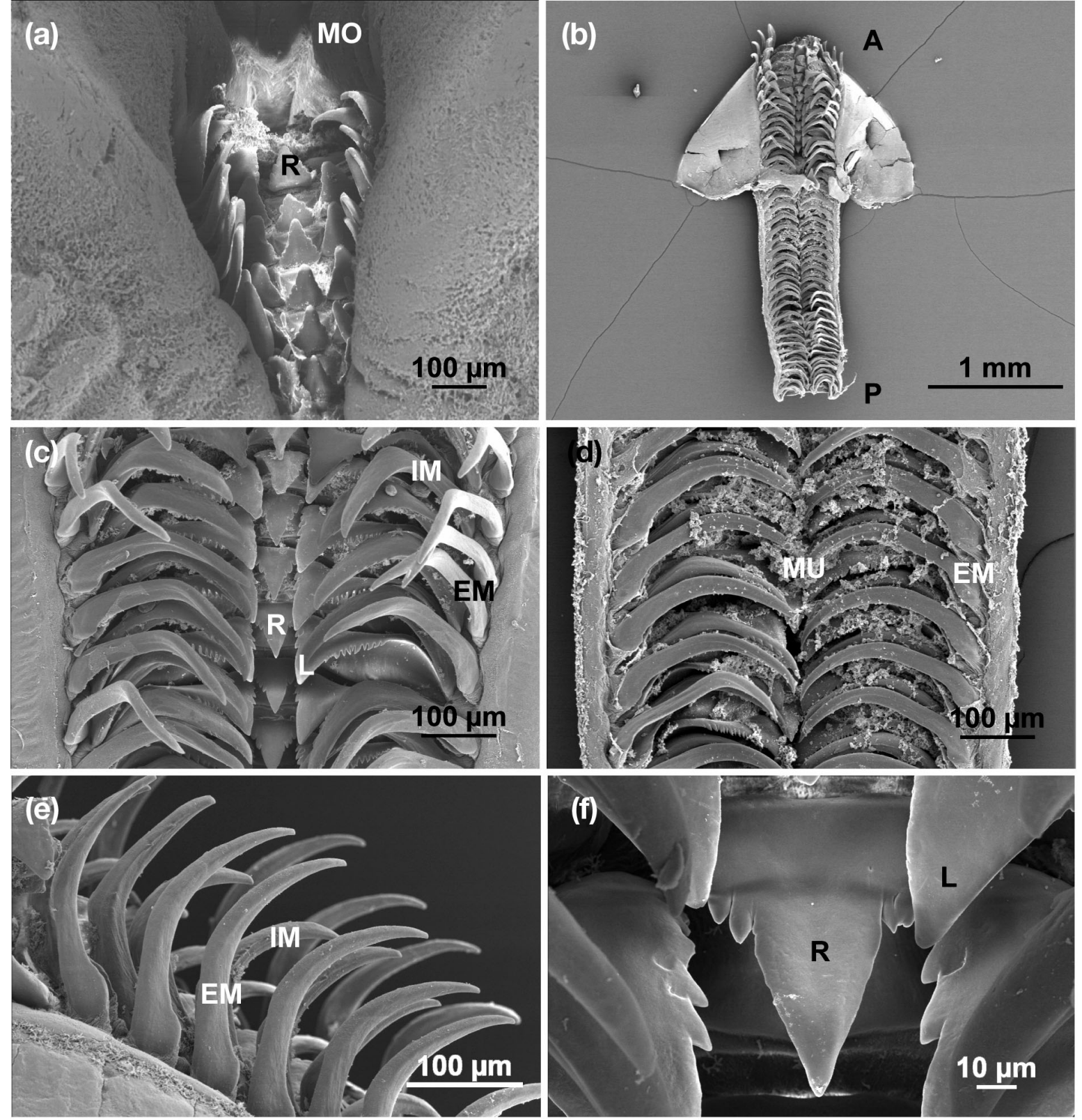

Fig. 2. Crepidula fornicata. Scanning electron micrographs of radulae. (a) View of radula in the mouth (MO). R, rachidian teeth. (b) General frontal view. A, anterior; P, posterior. (c,d) Frontal detailed views showing teeth arrangement. EM, external marginal teeth; IM, internal marginal teeth; L, lateral teeth; MU, mucus. (e) Lateral detailed view. (f) Rachidian and lateral teeth 
particle transport over the gill, transfer of a mucus cord from the ventral gill extremity to the particle canal on the neck (Fig. 3b), allocation of some of the cord to the particle pouch and the rest to the mouth, ingestion using the stereotypical flexing movement of the long marginal radular teeth (Fig. 3c), and rejection from both the particle pouch and mouth region following prolonged exposure to high particle concentration (Condi-
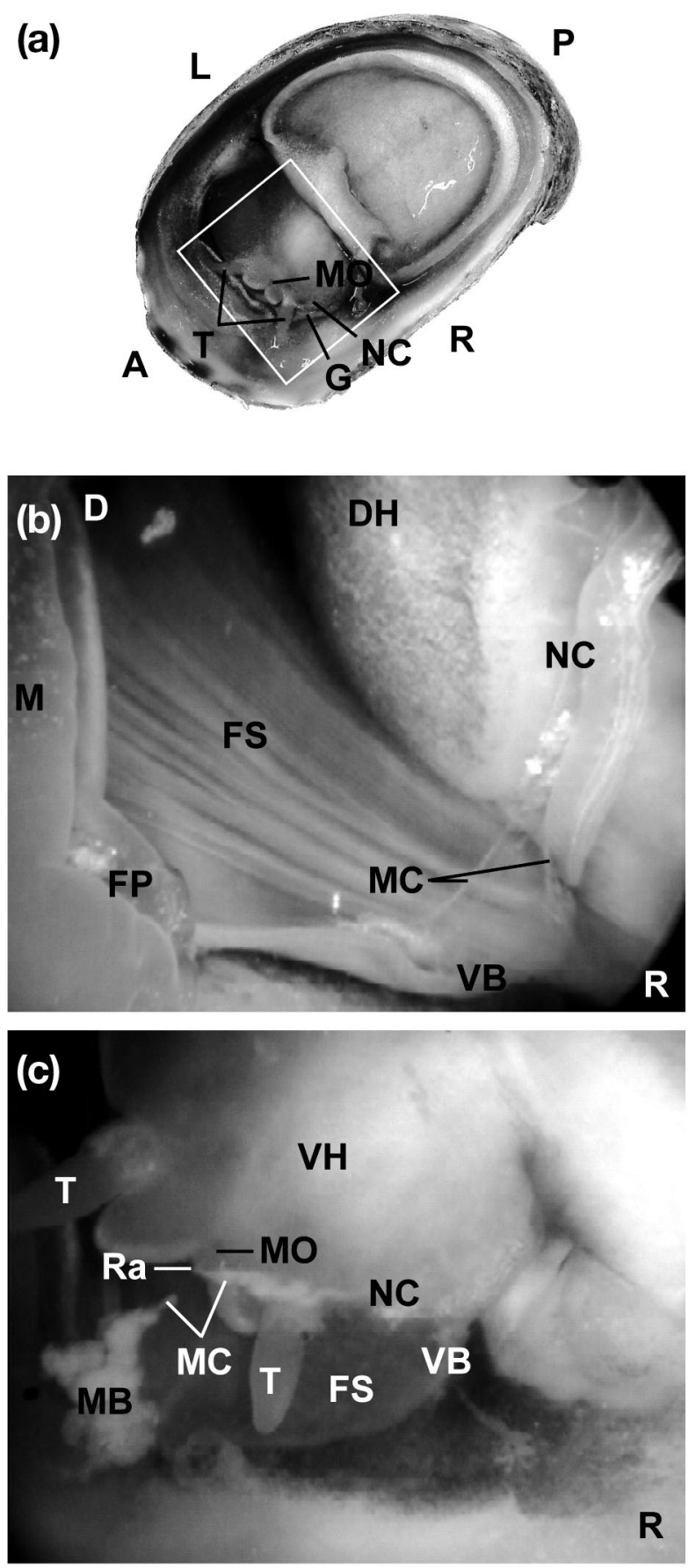

tion 2). Both from the vantage point of our OIT, and due to the extreme sensitivity of the cephalic region, we were unable to observe particle processing on the abfrontal surface of the gill.

\section{Selection experiments: Crepidula fornicata and Crassostrea gigas}

No difference in aspect of ppseudofeces (sensu Chaparro et al. 2004) was observed in either of the particle concentrations. At both particle concentrations (Condition 1 and Condition 2), significant differences in intact cell proportions were observed between pseudofeces of oysters and slipper limpets, and control chamber waters (1-way ANOVA: $\mathrm{df}=3, F=12.845$, p < 0.001 and $F=7.445, \mathrm{p}<0.001$ for Conditions 1 and 2, respectively). There was a significantly greater proportion of empty frustules in the pseudofeces of Crassostrea gigas than in the corresponding control chamber outflow (Tukey's test: $\mathrm{p}<0.001$ and $\mathrm{p}=0.028$ for Conditions 1 and 2, respectively), but no significant difference in the proportion of empty frustules in the pseudofeces of $C$. fornicata compared with the corresponding control chamber outflow (Tukey's tests: $\mathrm{p}=$ 1.000 and $\mathrm{p}=0.684$ for Conditions 1 and 2, respectively; Fig. 4). This was reflected in the selection indices: C. gigas exhibited a significantly greater selection index than did $C$. fornicata (2-way ANOVA: $\mathrm{df}=1, F=46.223, \mathrm{p}<0.001$; Tukey test: $\mathrm{p}<0.001$ for Conditions 1 and 2; Fig. 5), but no difference in selection efficiency between Conditions 1 and 2 was observed ( 2 -way ANOVA: df $=1, F=0.751, p=0.391$ ). We therefore reject $H_{0}$ (no qualitative selection), and accept $H_{1}$ : C. gigas employs qualitative selection. Furthermore, we accept $H_{0}$ for $C$. fornicata, and concluded that the slipper limpet exhibited no qualitative selection under the experimental conditions of the present study.

Examination of the 5 haphazardly selected Crepidula fornicata specimens fed ad lib. with Coscinodiscus perforatus var. pavillardii at the end of the experiments revealed the presence of the diatom in both the stomach contents and feces of all individuals (Fig. 6).

Fig. 3. Crepidula fornicata. (a) General ventral view, whole specimen. A, anterior; G, gill; L, left; NC, neck canal; $\mathrm{MO}$, mouth; $\mathrm{P}$, posterior; $\mathrm{R}$, right; $\mathrm{T}$, tentacle. $(\mathrm{b}, \mathrm{c})$ Video-endoscopic images showing (b) transfer of a mucus cord (MC) from ventral bulbs (VB) to the neck canal, and (c) ingestion of mucus cords from the neck canal (visible by semi-transparency of the neck canal), and from a mucus ball (MB) in the food pouch (FP). D, dorsal; $\mathrm{DH}$, dorsal side of the head; FS, frontal gill surface; $\mathrm{M}$, mantle; $\mathrm{Ra}$, radula; $\mathrm{VH}$, ventral side of the head 
(a)

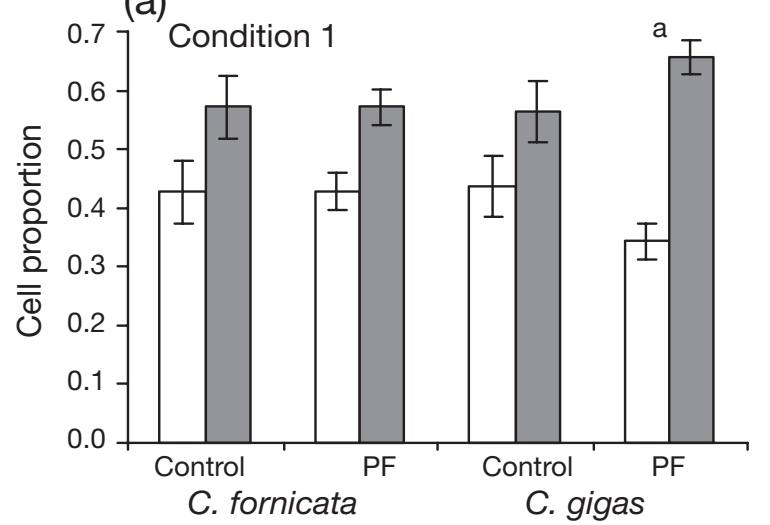

(b)

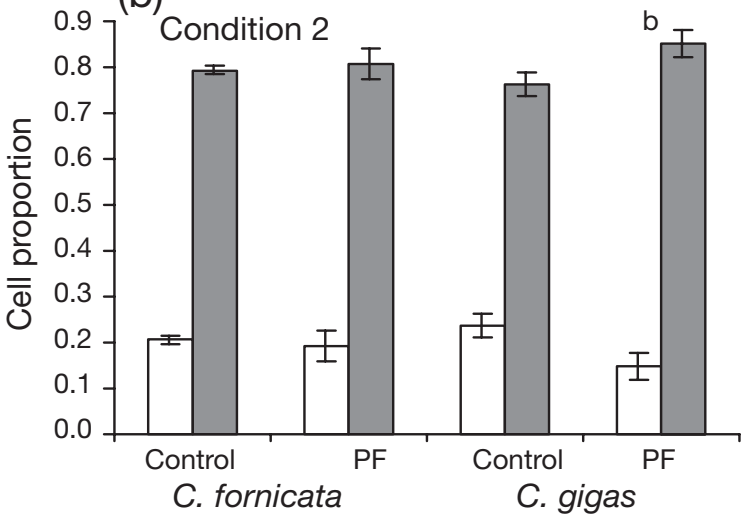

Fig. 4. Coscinodiscus perforatus var. pavillardii. Mean proportions of intact cells (white bars) and empty frustules (grey bars) in control chamber outflows (mean values of water sampled every $30 \mathrm{~min}$ up to $120 \mathrm{~min}$ ) and in pseudofaeces (PF, final value at $120 \mathrm{~min}$ ) of 12 Crepidula fornicata and 12 Crassostrea gigas specimens. (a) Condition 1; (b) Condition 2. See table 1 for Condition concentrations. Error bars are SD. Bar pairs with letters differ significantly from other bar pairs in the same graph (1-way ANOVA, $p<0.001$; Tukey test: [Condition 1] $p<0.001$, [Condition 2] $p<0.001, p=0.002$, and $p=0.028$ for comparisons with ' control C. fornicata', 'PF C. fornicata' and 'control C. gigas', respectively)

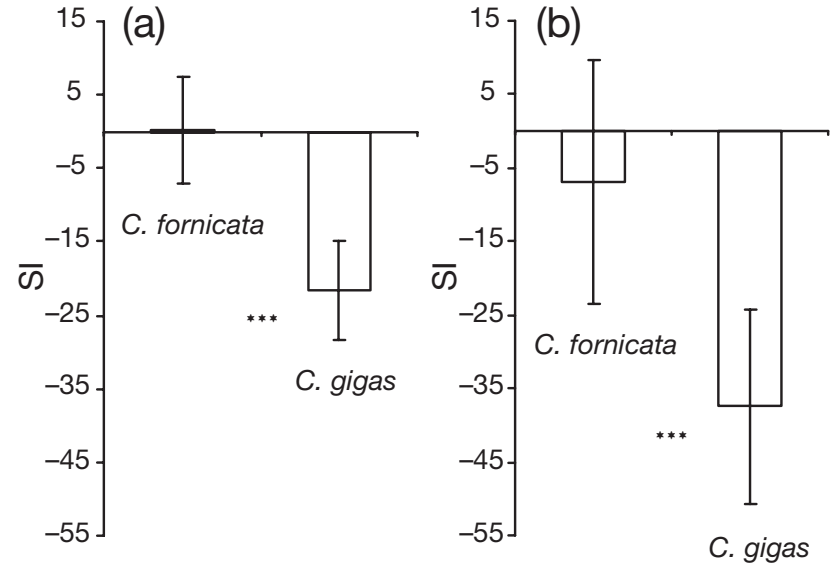

Fig. 5. Mean selection index (SI) in Crepidula fornicata and Crassostrea gigas for (a) Condition 1 and (b) Condition 2. Error bars are SD. ${ }^{* * *} \mathrm{p}<0.001$

\section{DISCUSSION}

Although our anatomical and video-endoscopic data corroborate older reports on Crepidula fornicata (Orton 1912, 1914, Werner 1951, 1953), as well as the more recent study on C. fecunda (Chaparro et al. 2002), several basic aspects of the feeding processes of the slipper limpet remain poorly understood, as outlined below.

\section{Anatomy and function of Crepidula fornicata feeding structures}

Given the ventral position of the OIT, it was not possible to observe events, if any, on the abfrontal surface. Initially, Orton (1912) described similar particle trans-
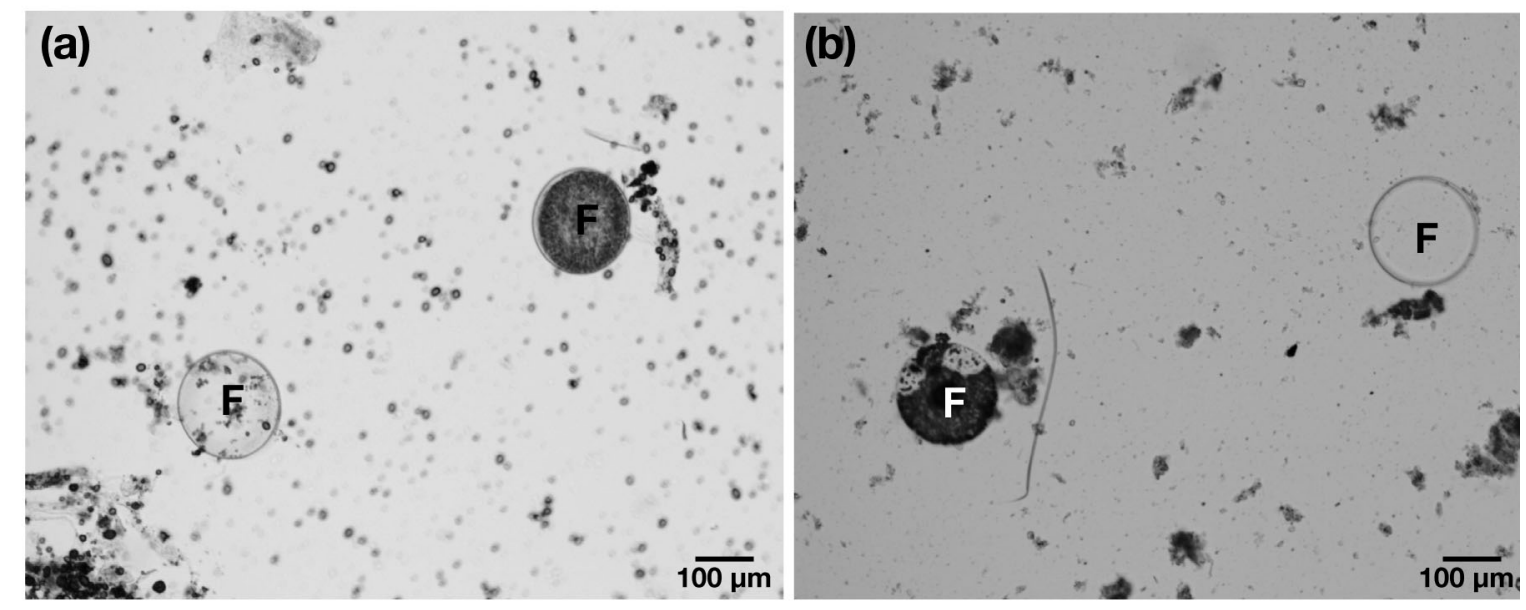

Fig. 6. Light micrographs of unstained Coscinodiscus perforatus var. pavillardii frustules (F) in (a) stomach content and (b) feces of slipper limpets 
port over both the frontal and abfrontal surfaces of specimens removed from their shells, in which the gill assumes a tuft form rather than the sheet form in life. He later retracted this statement (Orton 1914), arguing that the cilation of the abfrontal surface probably assisted in water pumping only. This certainly brings the Crepidula fornicata gill in line with other such suspension-feeding surfaces (Jones et al. 1990), but particle transport over the abfrontal surface was again reported (with no supporting micrographs) by Chaparro et al. (2002). The processing role, if any, of the abfrontal surface therefore requires further demonstration.

The morphology of Crepidula fornicata gill filaments is intriguing for a suspension-feeding mollusk, when compared to that of bivalve gill filaments. In autobranch bivalves, the frontal surface is always larger than the abfrontal surface, affording a greater surface area for particle processing, whereas the opposite is true in C. fornicata. To our knowledge, this question has not been studied (or indeed even mentioned) in the literature, but it is interesting to relate this situation with the changes in gill morphology as a result of gastropod torsion (Yonge 1947).

The role of the particle pouch is also not yet fully clear. The quantitative observations of Chaparro et al. (2004) on Crepidula fecunda suggest that the mucus balls formed here undergo the same fate as that of the mucus-particle cord, and that it plays a minor role in particle processing (5 to $15 \%$ of the processed material). Given this, we suggest that the particle pouch functions as a temporal buffer, allowing temporary diversion of excess material while the radula intercepts what it can under high particle concentrations. With regard to the size of mucus balls and number of radular extrusions required to ingest them, the particle pouch certainly appears to reflect increasing particle concentrations (Chaparro et al. 2004).

The existence of a mucus net at the inhalent entry (reported by Orton 1912, and in many subsequent works, e.g. Werner 1951, 1959, Franc 1968, Purchon 1977, Chaparro et al. 2002, 2004) has never been substantiated photographically. It is difficult to imagine a mucus net being formed without an underlying netshaped surface to form and support it (Flood 1981, Flood \& Fiala-Médioni 1981), and such a net was not observed by video-endoscopy in the present study. As it may be argued that this 'net' collapses upon disturbing the animal (e.g. the illumination of our endoscope optical tube), the question remains open, but improbable. Similarly, the existence of a mucus net on the gill (first mentioned by Orton [1912] and subsequently by Jørgensen et al. [1984] and Chaparro et al. [2002]) has never been unequivocally demonstrated; here it is again difficult to imagine transverse fibers when the gill is composed only of longitudinal filaments.
Finally, while the role of the radula is quite clear in the observed interception of the mucus-particle cord arriving in the buccal region in the adults examined, several intriguing differences may be noted between the radulae of Crepidula fornicata and those of C. fecunda adults (Chaparro et al. 2001). The C. fornicata rachidian and lateral teeth do not show any rounding or blunting, and the marginal teeth are somewhat finer and much more angled than those of $C$. fecunda. It has been suggested that $C$. fecunda females prepare the substrate by rasping prior to oviposition (Chaparro et al. 2001); therefore, the rounding of the rachidian and lateral teeth may be mechanically induced. In general, gastropods that undergo marked, often ontogenetic dietary changes also undergo morphological changes of the radula (Padilla 1998, Onitsuka et al. 2004); it would therefore be of interest to compare the radular structure of $C$. fornicata adults with that of juveniles. The more substantial morphological difference of the marginal teeth may be a species-specific character, rather than a diet-induced difference, since both species are suspensivores in the adult stage.

\section{Crepidula fornicata feeding organs: no potential for selection}

Table 2 summarizes the salient features of both the Crassostrea gigas and Crepidula fornicata feeding structures with respect to their potential for selection. Although the C. gigas gills and labial palps present several key adaptations that render their observed selection ability possible (Ward et al. 1998, Cognie et al. 2003, present study), the $C$. fornicata gills and radula show no features that would enable selection to take place. The particle pouch is the only structure for which no judgement may be made, since its mode of action is unknown. However, as a simple fold of the mantle, with no visible reduction of mucus-particle mass viscosity as in oysters and other bivalves (Newell \& Jordan 1983, Beninger \& St-Jean 1997a,b), it is unlikely that the food pouch is capable of selection. The anatomical-functional data are therefore consistent with $H_{0}$ of no qualitative selection in C. fornicata.

\section{Selection experiments: Crassostrea gigas and Crepidula fornicata}

The results of selection experiments clearly show that under identical experimental conditions, Crassostrea gigas exhibits significant qualitative selection ( $H_{0}$ rejected, $H_{1}$ accepted), whereas Crepidula fornicata exhibits no significant (Fig. 4) or even negligible (Fig. 5a) ability for selection $\left(H_{0}\right.$ accepted). Experi- 
Table 2. Crepidula fornicata and Crassostrea gigas. Comparison of anatomical and functional characteristics of feeding structures. ADMPS, acid-dominant mucopolysaccharide; AMPS, acid mucopolysaccharide; OF, ordinary filament; PF, principal filament

\begin{tabular}{|c|c|c|c|c|}
\hline \multirow[t]{2}{*}{ Characteristic } & \multicolumn{2}{|c|}{ Crassostrea gigas } & \multicolumn{2}{|c|}{ Crepidula fornicata } \\
\hline & Pertinent feature & Functional consequence & Pertinent feature & Functional consequence \\
\hline \multicolumn{5}{|l|}{ Gill } \\
\hline Gill type & $\begin{array}{l}\text { Heterorhabdic, } \\
\text { filamentar fusion }\end{array}$ & $\begin{array}{l}\text { Particle selection enabled; } \\
\text { highly directed water flow }\end{array}$ & $\begin{array}{l}\text { Homorhabdic, } \\
\text { free filaments }{ }^{c}\end{array}$ & $\begin{array}{l}\text { Particle selection difficult; } \\
\text { single water flow }\end{array}$ \\
\hline $\begin{array}{l}\text { 3D configuration } \\
\text { (natural state) }\end{array}$ & Plicate $^{\mathrm{a}}$ & $\begin{array}{l}\text { Particle selection facilitated } \\
\text { by isolating acceptance and } \\
\text { rejection tracts, and by exposing } \\
\text { particles to 'staggered' trajectory } \\
\text { from OF crest to PF, thus } \\
\text { enabling qualitative evaluation }\end{array}$ & Flat $^{\mathrm{c}}$ & $\begin{array}{l}\text { Particle selection not } \\
\text { facilitated }\end{array}$ \\
\hline $\begin{array}{l}\text { Filament } \\
\text { folding }\end{array}$ & V-shape ${ }^{a}$ & $\begin{array}{l}\text { Surface area increased, } \\
\text { more complex processing } \\
\text { possible (selection) }\end{array}$ & Straight ${ }^{\mathrm{c}}$ & $\begin{array}{l}\text { Small surface area, } \\
\text { favours simple processing } \\
\text { (no selection) }\end{array}$ \\
\hline Mucocytes & $\begin{array}{l}\text { AMPS and ADMPS, } \\
\text { differentially } \\
\text { distributed }^{\mathrm{b}}\end{array}$ & $\begin{array}{l}\text { Division of labour possible } \\
\text { (including selection) }\end{array}$ & AMPS only ${ }^{\mathrm{c}}$ & $\begin{array}{l}\text { No division of labour } \\
\text { (no selection) }\end{array}$ \\
\hline $\begin{array}{l}\text { Latero-frontal } \\
\text { cirri }\end{array}$ & Present $^{a}$ & $\begin{array}{l}\text { Direct ciliary interception } \\
\text { of particles possible }\end{array}$ & Absent $^{\mathrm{c}}$ & $\begin{array}{l}\text { Particles must be intercepted } \\
\text { indiscriminately on mucus- } \\
\text { laden frontal (and abfrontal?) } \\
\text { surfaces }\end{array}$ \\
\hline \multicolumn{5}{|l|}{ Peribuccal organ } \\
\hline Type & $\begin{array}{l}\text { Complex, muscular } \\
\text { labial palps }{ }^{\mathrm{a}}\end{array}$ & $\begin{array}{l}\text { Selection and ingestion } \\
\text { volume regulation enabled }\end{array}$ & $\begin{array}{l}\text { Chitinous } \\
\text { flexoglossate } \\
\text { radula and } \\
\text { simple particle } \\
\text { pouch }^{\mathrm{c}}\end{array}$ & $\begin{array}{l}\text { Indiscriminate transfer and } \\
\text { grasping of mucus-particle } \\
\text { masses only }\end{array}$ \\
\hline $\begin{array}{l}\text { 3D configuration } \\
\text { (natural state) }\end{array}$ & Plicate oral surface ${ }^{a}$ & Established selection site & Spiny teeth ${ }^{\mathrm{c}}$ & No selection capacity \\
\hline Ciliated tracts & $\begin{array}{l}\text { Complex sorting } \\
\text { tracts on oral surface }\end{array}$ & Selection effected & Absent $^{c}$ & No selection capacity \\
\hline \multicolumn{5}{|l|}{${ }^{\mathrm{a}}$ Gosling (2003) } \\
\hline \multicolumn{5}{|c|}{${ }^{\mathrm{b}}$ Beninger et al. (2005) } \\
\hline${ }^{\mathrm{C}}$ Present study & & & & \\
\hline
\end{tabular}

mental results for C. gigas are thus in accordance with those of previously published studies (Pastoureaud et al. 1996, Barillé et al. 1997, Ward et al. 1998, Cognie et al. 2003), while the experimental results for C. fornicata are in line with the present study's data concerning feeding structures. Therefore, in addition to differences in retention and clearance rates between these 2 species, experimental results from Conditions 1 and 2 of the present study suggest a fundamental difference in particle processing between these introduced, sympatric suspensivores: C. gigas is capable of selective feeding, whereas $C$. fornicata is not. In view of the anatomical data highlighted in the present study, it is likely that this conclusion may be extended to a general absence of selection ability.

Together with the retention profiles of these 2 species (Barillé et al. 2006), the absence of selection ability in Crepidula fornicata means that their diets overlap de facto. The next step in evaluating the degree of trophic competition between these species is to quantitatively determine the degree of such overlap. As a result of the non-selective nature of $C$. fornicata feeding, this next step cannot proceed via analysis of gut contents, since this does not convey the same information for each of the 2 species. In Crassostrea gigas, preingestive selection means that there is an enhanced probability of assimilation of metabolites from gut contents, whereas in C. fornicata, gut contents give no information on likelihood of assimilation. The analysis of gut contents is thus of limited use in determining what food sources are used by C. fornicata compared with C. gigas: this information must instead be obtained from stable isotope analysis (Peterson 1999, Thompson et al. 2005). However, in an ecosystem context, gut contents analysis will indicate what types of particles are sequestered by these 2 suspensivores and subjected to modified bioavailability after biodeposition. 


\section{Comparative advantages of selective and non- selective suspensivore strategies}

To our knowledge, this study represents the first demonstration of the existence of sympatric selecting and non-selecting suspensivores. Qualitative selection may only be expected to be advantageous when the proportion of high value particles is large; when the proportion of high value particles is small, qualitative selection is not advantageous, and may in fact be disadvantageous owing to increased processing costs (Sierszen \& Frost 1992). Since the selective ability of bivalves is facultative (Navarro \& Widdows 1997, Bacon et al. 1998, Velasco \& Navarro 2002, Navarro et al. 2004), oysters may be able to optimize feeding through modulation of their selection ability: the function may be engaged during phytoplankton blooms or tidal resuspension of microphytobenthos, and disengaged otherwise (low proportion of organic matter, ingestion volume control only). In this way, oysters could compensate for low seston quality, and hence thrive in the high-turbidity habitats in which they are frequently encountered. Indeed, the heterorhabdic gill found in oysters and scallops is a bivalent adaptation, conducive both to qualitative particle selection and to discharge of excess particulate matter (Beninger et al. 2004). Crepidula fornicata may prosper in the same turbid habitats because the majority of the annual cycle is characterized by low proportions of high value particles, for which the non-selecting mode is best suited. It has been suggested that in contrast to most bivalves, the open, straight-filament collecting surface of brachiopods enables them to thrive in turbid waters, because the open design allows excess particles to easily bypass the collecting surfaces (Steele-Petrovic 1975). The C. fornicata gill shows a similar type of design, which may indeed assist this species to tolerate the turbid habitats where oysters are cultured. The closed, heterorhabdic gill of oysters, together with their efficient pseudofeces-production mechanisms, may represent a different mechanism of the same adaptive strategy: instead of a loose gill system that allows excess particles to be easily shunted through the mantle cavity, as in C. fornicata, the oyster system allows continuous rejection of excess particles involuntarily intercepted by its gill.

\section{Implications for trophic competition}

As indicated above, the non-selective feeding mode and retention profile of Crepidula fornicata signifies that its diet must overlap that of Crassostrea gigas. The difference in the qualitative selection ability of these 2 suspensivores means that the degree of trophic compe- tition may depend in part on the activation/deactivation of selective feeding in C. gigas, itself determined by environmental variables. This could be investigated using the stable isotope approach (in progress). The present study's unequivocal demonstration of the differing selective ability of these 2 species under controlled laboratory conditions should enable future research to construct protocols - and ultimately ecosystem models - that take this fundamental difference into consideration.

Acknowledgements. We thank Mad. M. Gaill, A. Ham-Cheney and O. Aumaille for their technical assistance, M. Lamour and crew of the SNSM Search and Rescue vessel 'Georges Clemenceau II' for facilitating the plankton tow, and M. A. Barreau for assistance with SEM. Our apologies to the numerous authors cited in previous versions of this manuscript but not in the final owing to space limitations. This project was partially funded by the Conseil de la Région Pays de la Loire through operating funds and a doctoral scholarship to P.D.

\section{LITERATURE CITED}

Bacon GS, MacDonald BA, Ward JE (1998) Physiological responses of infaunal (Mya arenaria) and epifaunal (Placopecten magellanicus) bivalves to variations in the concentration and quality of suspended particles. I. Feeding activity and selection. J Exp Mar Biol Ecol 219:105-125

Barillé L, Prou J, Héral M, Razet D (1997) Effects of high natural seston concentrations on the feeding, selection, and absorption of the oyster Crassostrea gigas (Thunberg). J Exp Mar Biol Ecol 212:149-172

Barillé L, Cognie B, Beninger PG, Decottignies P, Rincé Y (2006) Feeding responses of the gastropod Crepidula fornicata to changes in seston concentration. Mar Ecol Prog Ser 322:169-178

Beninger PG, Decottignies P (2005) What makes diatoms attractive for suspensivores? The organic casing and associated organic molecules of Coscinodiscus perforatus are quality cues for the bivalve Pecten maximus. J Plankton Res 27:11-17

Beninger PG, St-Jean SD (1997a) Particle processing on the labial palps of Mytilus edulis and Placopecten magellanicus (Mollusca: Bivalvia). Mar Ecol Prog Ser 147:117-127

Beninger PG, St-Jean SD (1997b) The role of mucus in particle processing by suspension-feeding marine bivalves: unifying principles. Mar Biol 129:389-397

Beninger PG, St-Jean S, Poussart Y, Ward JE (1993) Gill function and mucocyte distribution in Placopecten magellanicus and Mytiluis edulis (Mollusca: Bivalvia): the role of mucus in particle transport. Mar Ecol Prog Ser 98:275-282

Beninger PG, Dufour SC, Decottignies P, Le Pennec M (2003) Particle processing mechanisms in the archaic, perihydrothermal vent bivalve Bathypecten vulcani, inferred from cilia and mucocyte distributions on the gill. Mar Ecol Prog Ser 246:183-195

Beninger PG, Decottignies P, Rincé Y (2004) Localization of qualitative particle selection sites in the heterorhabdic filibranch Pecten maximus (Bivalvia: Pectinidae). Mar Ecol Prog Ser 275:163-173

Blanchard M (1995) Origine et état de la population de Crepidula fornicata (Gastropoda Prosobranchia) sur le littoral français. Haliotis 24:75-86 
Blanchard M (1997) Spread of the slipper limpet Crepidula fornicata (L. 1758) in Europe. Current state and consequences. Sci Mar 61:109-118

Bougrier S, Hawkins AJS, Héral M (1997) Preingestive selection of different microalgal mixtures in Crassostrea gigas and Mytilus edulis, analysed by flow cytometry. Aquaculture 150:123-134

Chaparro OR, Pereda SV, Bahamondes-Rojas I (2001) Effects of protandric sex change on radula, pedal morphology, and mobility in Crepidula fecunda (Gastropoda : Calyptraeidae). NZ J Mar Freshw Res 35:881-890

Chaparro OR, Thompson RJ, Pereda SV (2002) Feeding mechanisms in the gastropod Crepidula fecunda. Mar Ecol Prog Ser 234:171-181

Chaparro OR, Segura CJ, Navarro JM, Thompson RJ (2004) The effect of food supply on feeding strategy in sessile female gastropods Crepidula fecunda. Mar Biol 144:79-87

Cognie B, Barillé L, Massé G, Beninger PG (2003) Selection and processing of large suspended algae in the oyster Crassostrea gigas. Mar Ecol Prog Ser 250:145-152

Davis MA, Thompson K (2000) Eight ways to be a colonizer; two ways to be an invader: a proposed nomenclature scheme for invasion ecology. Bull Ecol Soc Am 81:226-230

Declerck CH (1995) The evolution of suspension feeding in gastropods. Biol Rev 70:549-569

de Montaudouin X, Sauriau PG (1999) The proliferating Gastropoda Crepidula fornicata may stimulate macrozoobenthic diversity. J Mar Biol Assoc UK 79:1069-1077

de Montaudouin X, Audemard C, Labourg PJ (1999) Does the slipper limpet (Crepidula fornicata, L.) impair oyster growth and zoobenthos biodiversity? A revisited hypothesis. J Exp Mar Biol Ecol 235:105-124

Flood PR (1981) On the ultrastructure of mucous. Biomed Res 2: $49-53$

Flood PR, Fiala-Médioni A (1981) Ultrastructure and histochemistry of the food trapping mucous film in benthic filterfeeders (Ascidians). Acta Zool 62:53-65

Franc A (1968) Sous-Classe des Prosobranches. In: Grassé PP (ed) Traité de zoologie - anatomie, systématique, biologie, Tome V Fasc. III: mollusques, gastéropodes et scaphopodes. Masson, Paris, p 40-324

Guralnick R, Smith K (1999) Historical and biomechanical analysis of integration and dissociation in molluscan feeding, with special emphasis on the true limpets (Patellogastropoda: Gastropoda). J Morphol 241:175-195

Haure J, Baud JP (1995) Approche de la capacité trophique dans un bassin ostréicole (Baie de Bourgneuf). Rapport Ifremer RIDRV-95-16/RA-BOUIN:1-103

Jackson JBC, Kirby MX, Berger WH, Bjorndal KA and 15 others (2001) Historical overfishing and the recent collapse of coastal ecosystems. Science 293:629-638

Jones HD, Richards OG, Hutchinson S (1990) The role of ctenidial abfrontal cilia in water pumping in Mytilus edulis L. J Exp Mar Biol Ecol 143:15-26

Jørgensen CB, Kiørboe T, Møhlenberg F, Riisgård HU (1984) Ciliary and mucus-net filter feeding, with special reference to fluid mechanical characteristics. Mar Ecol Prog Ser 15: 283-292

Le Pape O, Guérault D, Désaunay Y (2004) Effect of an invasive mollusc, American slipper limpet Crepidula fornicata, on habitat suitability for juvenile common sole Solea solea in the Bay of Biscay. Mar Ecol Prog Ser 277:107-115

Marteil L (1965) Extension de l'aire géographique de Crepidula fornicata L. pendant l'année 1964. Bull Inf Doc Inst Sci Tech Pêch Marit 135:5-6

Minchin D, McGrath D, Duggan CB (1995) The slipper limpet, Crepidula fornicata (L.), in Irish waters, with a review of its occurence in the north eastern Atlantic. J Conchol 35: $249-256$

Navarro JM, Widdows J (1997) Feeding physiology of Cerastoderma edule in response to a wide range of seston concentrations. Mar Ecol Prog Ser 152:175-186

Navarro JM, Fernández-Reiriz MJ, Labarta U (2004) Shortterm feeding response of the scallop Argopecten purpuratus exposed to two different diets. J Mar Biol Assoc UK 84: 775-779

Newell RIE, Jordan SJ (1983) Preferential ingestion of organic material by the American oyster Crassostrea virginica. Mar Ecol Prog Ser 13:47-53

Okuno H (1970) Marine diatoms. In: Helmcke JG, Krieger W (eds) Diatomeenschalen im elektronenmikroskopischen bild, Vol VII. J Cramer, Lehre, p 4, plates 626-628

Onitsuka T, Kawamura T, Ohashi S, Horii T, Watanabe Y (2004) Morphological changes in the radula of abalone Haliotis diversicolor aquatilis from post-larva to adult. J Shellfish Res 23:1079-1085

Orton JH (1912) The mode of feeding of Crepidula, with an account of the current-producing mechanism in the mantle cavity, and some remarks on the mode of feeding in gastropods and lamellibranchs. J Mar Biol Assoc UK New Ser 9:444-478

Orton JH (1914) On ciliary mechanisms in brachiopods and some polychaetes, with a comparison of the ciliary mechanisms on the gills of molluscs, Protochordata, brachiopods, and cryptocephalous polychaetes, and an account of the endostyle of Crepidula and its allies. J Mar Biol Assoc UK 10:283-311

Padilla DK (1998) Inducible phenotypic plasticity of the radula in Lacuna (Gastropoda: Littorinidae). Veliger 41:201-204

Palmer RE, Williams RE (1980) Effect of particle concentration on filtration efficiency of the bay scallop Argopecten irradians and the oyster Crassostrea virginica. Ophelia 19: 163-174

Pastoureaud A, Héral M, Prou J, Razet D, Russu P (1996) Particle selection in the oyster Crassostrea gigas (Thunberg) studied by pigment HPLC analysis under natural food conditions. Oceanol Acta 19:79-88

Peterson BJ (1999) Stable isotopes as tracers of organic matter input and transfer in benthic food webs: a review. Acta Oecol 20:479-487

Purchon RD (1977) The biology of the Mollusca. Pergamon Press, Oxford

Riera P, Stal LJ, Nieuwenhuize J (2002) $\delta^{13} \mathrm{C}$ versus $\delta^{15} \mathrm{~N}$ of cooccurring molluscs within a community dominated by Crassostrea gigas and Crepidula fornicata (Oosterschelde, The Netherlands). Mar Ecol Prog Ser 240:291-295

Sierszen ME, Frost TM (1992) Selectivity in suspension feeders: food quality and the cost of being selective. Arch Hydrobiol 123:257-273

Sokal RR, Rohlf FJ (1995) Biometry: the principles and practice of statistics in biological research. WH Freeman, New York

Steele-Petrovic HM (1975) An explanation for the tolerance of brachiopods and relative intolerance of filter-feeding bivalves for soft muddy bottoms. J Paleontol 49:552-556

Thieltges DW (2005) Impact of an invader: epizootic American slipper limpet Crepidula fornicata reduces survival and growth in European mussels. Mar Ecol Prog Ser 286: $13-19$

Thieltges DW, Strasser M, van Beusekom JEE, Reise K (2004) Too cold to prosper - winter mortality prevents population increase of the introduced American slipper limpet Crepidula fornicata in northern Europe. J Exp Mar Biol Ecol 311: 375-391

Thompson RJ, Bury SJ, Hobson KA, Wassenaar LI, Shannon JP 
(2005) Stable isotopes in ecological studies. Oecologia 144: $517-519$

Vallet C, Dauvin JC, Hamon D, Dupuy C (2001) Effect of the introduced common slipper shell on the suprabenthic biodiversity of the subtidal communities in the Bay of SaintBrieuc. Conserv Biol 15:1686-1690

Velasco LA, Navarro JM (2002) Feeding physiology of infaunal (Mulinia edulis) and epifaunal (Mytilus chilensis) bivalves under a wide range of concentrations and qualities of seston. Mar Ecol Prog Ser 240:143-155

Voltzow J (1994) Gastropoda: Prosobranchia. In: Harrison FW, Kohn AJ (eds) Microscopic anatomy of invertebrates, Vol 5: Mollusca I. Wiley-Liss, New York, p 111-252

Ward JE, Levinton JS, Shumway SE, Cucci T (1998) Particle sorting in bivalves: in vivo determination of the pallial organs of selection. Mar Biol 131:283-292

Editorial responsibility: Otto Kinne (Editor-in-Chief), Oldendorf/Luhe, Germany
Werner B (1951) Über die Bedeutung der Wasserstromerzeugung und Wasserstromfiltration für die Nahrungsaufnahme der ortsgebundenen Meeresschnecke Crepidula fornicata L. (Gastropoda Prosobranchia). Zool Anz 146:97-113

Werner B (1953) Über den Nahrungserwerb der Calyptraeidae (Gastropoda Prosobranchia). Morphologie, Histologie und Funktion der am Nahrungserwerb beteiligten Organe. Helgol Wiss Meeresunters 4:260-315

Werner B (1959) Das Prinzip des endlosen Schleimfilters beim Nahrungserwerb wirbelloser Meerestiere. Int Rev Gesamten Hydrobiol 44:181-215

Wonham MJ, O'Connor M, Harley CDG (2005) Positive effects of a dominant invader on introduced and native mudflat species. Mar Ecol Prog Ser 289:109-116

Yonge CM (1947) The pallial organs in the aspidobranch gastropoda and their evolution throughout the mollusca. Phil Trans R Soc Lond B 232:443-518

Submitted: January 30, 2006; Accepted: July 21, 2006 Proofs received from author(s): March 9, 2007 